\title{
Access to Secondary and Tertiary Education for All Refugees: Steps and Challenges to Overcome
}

\author{
Marina L. Anselme And Catriona Hands
}

\begin{abstract}
During situations of displacement, access for refugee youth to secondary educational initiatives is limited at best. However, upon the return of refugees, the national structure of their home country is most often weak and unstable. To ensure the economic, social, and political development of a society that has been severely affected by conflict or disaster, it is imperative that there be a youth population of capable, productive, and educated citizens who may provide an exit strategy from the situation. Future leaders must therefore be given the opportunity to promote the development both of themselves personally, and of their national structures, through learning-notably, secondary, vocational, and tertiary education. This paper underscores the need for and gaps in the provision of secondary educational initiatives, highlighting the many challenges involved in improving refugee youth access to both secondary and vocational education, and highlighting the issues that must be considered by policy and decision makers in order to facilitate and support such access.
\end{abstract}

\section{Résumé}

Pendant les situations de déplacement forcé, l'accès à l'éducation secondaire des jeunes réfugiés est réduit au maximum. Cependant, à partir du moment où ils peuvent retourner à leurs pays d'origine, son structure est en général affaiblit et instable. Afin d'assurer le développement économique, social et politique d'une société qui a été sévèrement troublée par un conflit ou catastrophe, il est impératif de compter sur une jeunesse compétente, éduquée et responsable d'un point de vue civique, et capable de créer et de soutenir une stratégie de sortie aux situations du passé. Les leaders de demain doivent avoir l'opportunité de se développer individuellement, mais également de développer leurs structures nationales, à travers l'éducation, notamment secondaire, professionnelle et tertiaire. Cet article souligne les besoins et les écarts existants en ce qui concerne la provision d'initiatives dans le domaine de l'éducation secondaire, remarquant les divers défis auxquels il faut faire face pour améliorer l'accès des jeunes réfugiés à l'éducation post-primaire (secondaire et professionnelle), et par voie de conséquence à l'éducation tertiaire. En outre, il souligne également les sujets qui devraient être considérés par les autorités politiques et décisionnaires compétentes afin de faciliter et soutenir ledit accès.

\section{Introduction}

Access to post-primary education creates long-term, sustainable growth and human development that is crucial for the rebuilding, stability, and recovery of states that have been weakened by conflict. Economic and social development in these situations is crucial, and therefore in order to ensure the future stability of a country recovering from a history of conflict or disaster, it is vital that future leaders are given the opportunity to promote their development, both nationwide and personally, through learning. Secondary education is thus integral to the rebuilding of an effective and reliable national structure.

Unfortunately, post-primary education is overlooked by most humanitarian donors, agencies, and organizations during the relief and reconstruction phase of humanitarian emergencies, as it "falls between the cracks" of development budgets for education, which typically concentrate solely on basic education for children, ignoring youth in the process. But these youth are typically one of the most neglected groups of people by aid organizations when it comes to providing assistance to the displaced. Youth who are left without access to secondary education are left idle and unproductive, susceptible to recruitment into rebel movements, violent gangs, and all forms of exploitation 
including sexual abuse and illegal employment. Whether formal or non-formal, secondary education, including vocational training, provides a bridge to tertiary studies and employment, offering (and sustaining) physical, cognitive, and psychosocial security, protection, and self-reliance. Essentially, secondary learning bridges the gaps between conflict and peace, between dependency and self-reliance, between primary and post-primary, and between secondary and tertiary education or sustainable employment.

The Refugee Education Trust (RET) has run educational programs for displaced, refugee, and returnee youth for over ten years in countries that are either in conflict, coming out of conflict, devastated by natural disasters, or at high risk of violence. The RET has a focus on not just the relief needs of refugees and internally displaced youth and communities, but also the developmental needs of returnees. The provision of education and self-reliance to youth is important at such a vulnerable age and time, bridging the gap between emergency needs of displaced youth and providing developmental solutions in the home and host country during and after repatriation. Whilst many UN agencies and international or national organizations offer protection, food, water, medical assistance, and primary education, the RET is the only organization focused exclusively on education for youth affected by conflict or disaster. In order to ensure stable societies, we need to counter the traumatizing and destructive experiences that war-affected youth have undergone. It is important that conditions are created that assist in producing positive and productive roles for youth in developing countries. An important way to avoid future conflict is through realizing and encouraging the dynamism and capacities of youth as the leaders of tomorrow's societies. Youth cohorts who are not given the opportunity to integrate into community and social structures are less able to acquire the skills they need for peaceful and constructive adult lives.

This article will consider the various factors involved in secondary education for refugees, examining the need for improved access, the main challenges faced by refugee youth and organizations working for their education in accessing and providing such programs, and the value of post-primary education in situations of displacement. Economic, social, and community development and the recovery of a nation are reliant upon the value of young leaders, able to lead the way out of poverty and post-conflict situations. However, this is dependent upon such potential leaders' access to valid secondary education. Recommendations made in the conclusion will stem from the RET's extensive experience in the field.

\section{Issues Surrounding the Needs at Secondary Level for Refugee Adolescents and Youth}

Being uprooted does not deny refugees their right to education, nor remove the states' responsibility to provide it. Nevertheless, refugee youth and adult access to appropriate learning and life skills during their exile is extremely difficult, in developing as well as in less developed countries. The provision of primary as opposed to secondary education for refugees has astonishing differences. Basic education, as one of the Millennium Development Goals and the main focus of the Education For All (EFA) initiative, is considered a priority over secondary education in nearly all humanitarian situations, and even then, it will consistently be left until the reconstruction phase of such emergencies, with health care, access to food and nutrition, clean water, and other forms of protection being prioritized, as expected. In the case of refugees, and in terms of international funding policies, the different stages of education are often perceived as independent compartments, instead of interdependent and interactive links in the educational process. However, the perspective of lifelong learning here is essential. In that respect, for instance, it has been proved that high rates of enrolment and the achievement of learning outcomes at primary level depend significantly upon the availability of post-primary educational opportunities. Likewise, it is widely acknowledged that children who attend pre-primary educational programs are better prepared to succeed in primary education later on, and the provision of non-formal literacy courses for youth and adults who had their schooling interrupted not only improves their personal capacities and competencies, but also can have a positive impact upon the promotion of school attendance for their children; youth are an important potential resource for the development and reconstruction of societies and countries recovering from conflict.

It is often the case that this gap between primary and postprimary education is correlated with situations of conflict or disaster, especially in countries with restricted economic opportunities and poor governance. Indeed, as Rose and Greesley $^{1}$ discuss, attention to post-basic education is crucial to mitigate the risk of fragility of these nations, through the attention to youth (particularly disaffected youth), and the promotion of a more solid national framework through support to post-primary education for national capacity development and recovery.

However, providing a general academic education is often either not enough, or not suitable for the particular context that a school or centre is operating under. It is important that there is emphasis on the benefits that vocational or income generation training can bring to both individuals and communities in forcibly displaced situations. 
Youth may not attend school if they and their families see little direct benefit from the education that is being provided. However, an improvement in attendance rates will have a positive impact in education outcomes of the concerned youth. If they understand that there are economical advantages (and therefore concrete improvement to their lives) to their attendance, this will lead to more demand for such courses, and therefore to an improvement in attendance rates, and in turn to greater numbers of skilled and educated youth. Economic dimensions to the development of adolescents and youth are crucial for improving their self-esteem, social status, and overall identity. ${ }^{2}$

Today, 80 per cent of the world's refugees live in less developed countries, with 42 million displaced people worldwide (15.2 million of those refugees). ${ }^{3}$ According to the Adolescents and Youth Task Team of the Inter-Agency Network for Education in Emergencies (INEE), approximately 35 per cent of refugees in the world today are young people aged between twelve and twenty-four. ${ }^{4}$ However, despite the fact that the numbers of refugees making up the migrant population has fallen, from 8.8 per cent in 2000 to 7.6 per cent in $2010,{ }^{5}$ the capacities of governments and aid agencies to provide continued and successful assistance to them has not significantly improved in terms of educational opportunities. According to the Women's Refugee Commission, ${ }^{6}$ only 6 per cent of all refugee youth of secondary school age were enrolled in secondary school in 2009. However, the provision of education for national, non-displaced youth (especially in countries experiencing conflict or disaster) is still remarkably poor, and this is something that urgently needs to be addressed as well.

For internally displaced persons (IDPs), the situation is often worse than it is for refugee youth. The lack of legal frameworks that outline and monitor their rights considerably result in a lack of access to services such as education, as does the absence of state capacity and will to provide it. According to Munoz (former UN Special Rapporteur to the Commission on Human Rights), it was estimated that as recently as 2008, 90 per cent of internally displaced persons around the world went without access to their right to education. ${ }^{7}$ As they still remain under the protection of their own government, they are reliant upon a state that often has neither the ability nor the disposition to provide services at all, and that often is the cause of their flight. In fact, UNHCR's mandate did not originally cover the protection of IDPs, though the agency has more recently recognized their needs and is now the foremost provider of protection to such displaced populations.

In humanitarian contexts, refugee and internally displaced adolescents and youth have the least access to formal education, as compared to youth who are not forcibly displaced. Many have not even completed their primary schooling and require a range of formal and non-formal educational options, ${ }^{8}$ and still to this day, governments and international stakeholders do not put education in the context of lifelong learning, ${ }^{9}$ instead focusing on the goal of providing at least a few years of primary education to those in need. The consequences of this can be dramatic because they can severely affect the capacity of the personal and national development of those involved, especially those in fragile areas that have been severely affected by conflict or disaster, perpetuating cycles of poverty, instability, dependency, and lack of good governance.

In addition, the concept of providing access to non-formal secondary programs for displaced youth is an increasingly important one. In many contexts the majority of displaced youth (and host country national youth) are out of school and unable to return to a traditional classroom setting. Schools and education facilitators (be they NGOs, UN agencies, host/national governments, etc.) need to realize this and be open to changing their approach by going to the youth where they are, rather than providing only a school environment. The RET has run programs that abide by this in many countries. For instance, the provision of Secondary Education through Distance Learning (SEDL) programs in Chad enables Sudanese displaced youth unable to attend formal secondary schooling in the Eastern Chadian camps' classrooms, where they may study for their exams on their own initiative, with study guides, group meetings, and regular monitoring by RET staff and "Peer Educators." These students, like those who attend the RET's formal classes, are able to sit for the Sudanese accredited certificates (which the RET prepares in collaboration with the International Africa University in Khartoum) at the end of each year, qualifying them for future work or study in Sudan and elsewhere in the region.

\section{Main Challenges Faced by Refugee Youth to Access and Succeed in Quality Secondary Education}

Today, forced migration is characterized by two major trends that impact upon the realization of rights and the achievement of long-term solutions: (1) an increase in the number of "urban refugees" and (2) an increase in protracted refugee situations, which affects not only urban refugees but refugees in general. For instance, with the increased number of refugees living in urban areas rather than rural or remote regions, ${ }^{10}$ "there is an inevitable increase in protracted refugee situations as the availability of solutions declines," 11 thus directly affecting the number of refugees globally and the "quasi-permanent" situations they are living in. Considering this, it is important to note that worldwide, refugees generally stay in exile an average of seventeen years. ${ }^{12}$ These 
trends frame the major challenges faced by refugee hosting countries: how might refugee youth access relevant, good quality educational and training programs that on the one hand will enable them to contribute in more meaningful ways to local economic and community development, and on the other will enable them to realize their individual capabilities and values of respect, justice, and responsible citizenship? Under these circumstances, several obstacles need to be overcome by individual stakeholders to achieve the realization of the right to education for refugee youth around the world, in particular in the areas where the need is greatest and the situations of displacement most protracted.

Challenge 1: Limited Implementation of the Existing Legal and Protection Instruments

In general terms, the presence of refugees in a country raises certain challenges-notably as to how to ensure that their human, social, economic, and political rights, including the right to education in the broadest sense, are upheldand for all, not only children. In spite of the importance of unsatisfied needs and the insufficiency of international support, refugee youth are not completely deprived of international legal instruments that pave the way to accessing their rights to a lifelong learning process, beyond the boundaries of basic education. It is not our intention to present an exhaustive portrait of all those instruments; however, here we will mention those that have broad state recognition.

According to the 1951 Refugee Convention, refugees are entitled to a range of civil, political, and socio-economic rights, including protection from refoulement, the right to work, housing, social security, and schooling. In general, refugees are entitled to the same human rights and assistance as other foreigners. Article 22 of the Convention deals with the right to public education. There is no requirement as to residence or lawful stay in the country of asylum for the enjoyment of this right. With respect to elementary education, states have obligations to accord to refugees the same treatment as they accord to their own nationals. ${ }^{13}$ This should, as a minimum, include access to pre-school and primary school. As elementary education is compulsory for everyone, asylum-seeking and refugee adults and children, who have not completed such education, are entitled to receive it on the same terms as the citizens of the country of asylum. There is no obligation to wait for the asylum procedures to commence or to be completed. Education other than elementary, such as secondary and higher education, should be accorded to refugees as favourably as possible. ${ }^{14}$ This implies access to studies; the recognition of foreign school certificates, diplomas, and degrees; the remission of fees and charges; and the award of scholarships.
International human rights law complements international refugee law and broadens the scope of the right to education for refugees. In that respect, the right to education is safeguarded in a number of other international instruments. ${ }^{15}$ And all of them underline the fact that access to education should be maintained on the basis of equal opportunity, regardless of the person's legal status, nationality, or gender. ${ }^{16}$ Besides, the 1966 Covenant on Economic, Social and Cultural Rights (ICESCR) and the 1989 Convention on the Rights of the Child (CRC) recognize that primary education must be made compulsory and available completely free of charge to everyone (the UN Committee on the Rights of the Child has indicated that a minimum of nine years of education, primary and secondary, is expected, and that free and compulsory primary education should comprise at least six years). These instruments further provide that secondary education, including technical and vocational training, must be generally available and accessible to all; i.e. access to such education should not be dependent on the student's capacity or ability. Higher education (e.g. college and university) must be accessible to all who qualify, with no discrimination on gender, age, ethnic, or any other grounds.

Nevertheless, most asylum countries' governmental policies are generally vague and unclear with regard to refugees' rights to non-compulsory education levels and programs. In that sense, refugee youth are therefore less protected than refugee children; and certainly much less favoured than their national peers. It is important to note that in some cases when refugee populations are compelled to live in camps and they remain there for years, access to and provision of education, particularly basic education, is very often better developed inside the camps than in the neighbouring local areas.

Unfortunately, however, refugee youth are rarely able to exercise and leverage the above such legal instruments, despite the strong arguments in their favour, in order to impel the provision of education.

\section{Challenge 2: The Need for Special Support}

Forced displacement interrupts the cycles of education; therefore, in order to catch up after months and even years deprived of education, refugee youth may need support to refresh and update their skills before accessing secondary educational opportunities, which will also prevent their failure or dropping out from school. Refresher courses during holiday time and accelerated learning programs are alternatives that could allow refugee youth access to post-primary education. Evidently, in countries with economic resources under serious strain, complementary and well-tailored educational programs aiming to fulfill the particular needs of 
refugee youth cannot be realized without the support of the host country stakeholders, the international donor community, and the intervention of expert educational organizations capable of proposing such initiatives. Otherwise, in the best-case scenario, the majority of refugee youth who have interrupted their education will be compelled to learn only basic life skills.

In Chad, the RET has been running an accelerated learning program for two of the six years the organization has been present in the twelve Eastern camps for Sudanese refugees. In response to the urgent need of students who are of secondary school age, but who have missed vital years of schooling due to their displacement, the RET provides this course of study, implemented through distance learning. Students are given three years of schooling in one, thus catching up in their studies so that they can complete their secondary education. All students must take three compulsory subjects (French or English, Islamic studies, and Arabic) and a minimum of four optional subjects from among twelve that are offered. In order for the students' education to not go to waste once they are repatriated, the RET holds an exclusive Memorandum of Understanding (MoU) with the Sudanese Ministry of Education that enables the refugee students based in Chad to take the Sudanese curriculum, and to sit for their exams in Chad (therefore eliminating the risks that travelling to Sudan for the tests can have on such youth). Through the SEDL program, the RET has reinforced the teaching skills of all "subject animators" by providing them with training on teaching methodologies, study-group management, health, human rights, and peace education. Subject animators organize their study-group lessons in the education centres built and supported by the RET, and lead the study-group lessons on a weekly basis.

Concerning peer-to-peer education, in 2009-2010, 100 "spill-over" students formed twelve learning groups and 180 new SEDL students formed twenty-four learning groups. All of the students in these groups benefit from the support of the different subject animators in each education centre. Each student who passes their exams receives an International Secondary School Certificate (ISSC) which is recognized by universities in Sudan and in surrounding Arabic countries. It is important to recognize that host and home national governments play a vital role in the provision of education to displaced and refugee youth; without such a MoU, the RET would not be able to promise these students access to employment or future study in their home country upon return.

\section{Challenge 3: The Costs of Post-primary Education}

Access to secondary and tertiary education is often not free (including for nationals). Both require more skilled teaching staff, school infrastructure, equipment, and learning materials, and these are all significantly more expensive than in primary education. Families affected by conflict or emergencies are often unable to meet these costs, with refugee girls often at a bigger disadvantage than refugee boys, due to economic disparities or cultural patterns. Scholarship programs are very limited, and most of the time will not cover the entire cost of education-related expenses (such as transportation, clothes, uniforms, food, and accommodation). Often, only refugees who are supported by their families are able to continue with their education, which reveals that the principle of égalité de chances regardless of the individual's socio-economic origin, gender, culture, and nationality is an unachievable goal for refugee youth populations. In that respect, when looking towards sustainable solutions to make secondary education a reality for refugee youth, it is imperative to broaden the boundaries of "individual learner support" to include measures that assist in income generation for their families. This impacts positively not only in terms of access to and retention in education, but also in increasing female participation in post-primary education.

\section{Challenge 4: Lack of Reliable Systems for Recognition and} Accreditation of Learning Outcomes

Access to secondary education remains very difficult for refugee youth because it depends on proven evidence of previous studies, economic resources, and proficiency in the local language. Refugee women and girls are often more severely affected by these criteria than refugee men and boys. As mentioned before, attendance in the educational cycle will have been interrupted by sudden displacement and, very often, refugee youth complete their education by attending different schools in different settings, and their chosen tertiary institutions may not recognize these or may not have entry systems in place that are sensitive to their educational background. Moreover, learners' previous educational experiences, even with appropriate documentation, are often not (or not fully) taken into account by the relevant educational authorities, who tend to refuse them access or to place them in an inappropriate education level. The inflexibility of placement procedures affects learners' access, continuity, and progression in their new education system. ${ }^{17}$ This situation is also prevalent in many refugee camp contexts. ${ }^{18}$

The 1951 Refugee Convention encourages the contracting States to recognize foreign school certificates, diplomas, and degrees, ${ }^{19}$ but there is a lack of consistency in application of these rights when it comes to the recognition and certification of refugee diplomas and other educational attainments. In addition, the securing of formal recognition of learning achievements and certification should be considered as an 
integrated principle from the beginning of any humanitarian response as well as in protracted situations

The timing of this type of response is critical in avoiding a scenario where learners lose years waiting for such certification or "permission" from governments. In Tanzania for instance, it took two years for the government to permit Burundian refugees to receive "formal" primary education. Previously the primary schools were called "Child Activity Centres" and were not able to provide refugee children with the same certification as formal schooling. Moreover, more years were needed to permit refugee youth to receive formal education. This is relevant both for refugees living in camps and for those living in urban areas. There have been few instances of cross-border recognition of examinations and curriculum, but those that do exist include, for instance, those in Tanzania for Burundian and Congolese refugees (during the five years working with and supporting the secondary education of Burundian and Congolese refugee youth, the RET ensured that their school examinations were recognized by the Ministry of Education of their country); in Guinea for Liberian and Sierra Leonean refugees; in Chad for Sudanese refugees; and in Pakistan for Afghan refugees, amongst others. However, there is a general lack of clear regulatory frameworks and consistent policies with regard to accreditation and validation, leaving refugees open to arbitrary treatment, and therefore unprotected. ${ }^{20}$

\section{Challenge 5: Differential Barriers to Access}

It is easy to assume that the above challenges faced by refugees are the core reasons why such youth find secondary education so challenging to access, including those challenges that governments of host countries (or national governments of IDPs) face in providing education to the displaced and returned. However, it is sometimes the case that there are underlying reasons why certain refugee youth may not be able to access the schooling even when it is provided. For instance there can be certain barriers set up by cultural norms and/or economic and family obligations, such as early marriage and child care obligations for young females, youth being required by families to stay at home and work or tend to agricultural income-generation activities if they are in rural areas, or other jobs requiring their attention and labour. Often it is the case that refugee and displaced young women and girls have married at an early age and/or have young children or elderly relatives to take care of, in addition to their household chores and responsibilities, and these obligations can create a huge barrier to their access to education. In addition, school closures due to lack of funding and maintenance, a lack of safety and security both at and en route, to school and bureaucratic restrictions ${ }^{21}$ can also have a negative impact on students' access to and attendance at school.

One issue that is seldom addressed during the sporadic provision of secondary education to refugees is that it is unrepresentative to define all refugee youth simply by their age or gender. Youth must be defined by various socio-economic, cultural, and political factors, in order that the provision of services to them is both accessible and relevant to their needs. For instance, physical or mental disabilities can have an extensive impact on access to services such as education. Taking these into consideration is vital if equality is to be reached in the provision of such services. Ethnicity is another actor to be taken into consideration-something that truly defines an individual's identity in most situations. A dilemma often seen in this field of intervention is how to ensure the curricula proposed for the refugee and displaced youth are relevant to their particular needs as well as recognized and officially validated by their home countries.

The RET, in places such as Afghanistan, Burundi, Latin America, and Chad, makes special effort in order ensure such issues are considered during program development and implementation. For instance, young women are encouraged to attend school in addition to their other responsibilities. In Afghanistan, for example, a daycare kindergarten centre for the young children of female students is provided and is utilized by more than 50 per cent of the student body, who bring their children to school (where they are provided with basic pre-primary education as well). This enables the students to concentrate on their studies whilst knowing that their children are safe and cared for. In Burundi, the RET works in boarding schools where both male and female students are resident, removing the burden of their livelihood from their families, who for the majority of the year have one less mouth to feed. It is essential that such factors are recognized as being critical in the provision of education, whether it be primary, secondary, vocational, or tertiary.

\section{Conclusion and Recommendations}

In 2000, at the World Education Forum in Dakar on Education For All, six goals were established to ensure that the learning needs of all children, youth, and adults would be met by 2015. Goal 3, "to promote learning and life skills for young people and adults," was welcomed by certain members of the international community as recognition of the urgent need to provide education beyond primary level. In parallel, and with a visionary perspective about the fields where human and financial investments should be improved and expanded, the former High Commissioner for Refugees, Sadako Ogata, launched the RET as an independent and non-partisan organization aiming to bridge the gaps between primary and post-primary 
education for adolescents and youth living in conflict- and post-conflict-affected regions around the world.

Today, ten years on, the International Year of Youth marks the recognition of the vulnerabilities and potentials of adolescents and youth when it comes to gaining life skills and transitioning to adulthood. The statement issued by the Heads of UN Entities for the Launch of the year commented (albeit briefly) upon the lack of development in the educational sector worldwide for underprivileged youth, including refugee youth: "Although youth literacy rates have improved considerably ... progress has been uneven, with sub-Saharan Africa and Southern and Western Asia falling behind. ${ }^{22}$ Their recognition of the need to increase investment in secondary education-"the minimum level of education needed to succeed in our increasingly globalized economy and to guarantee young people a smooth transition to decent jobs"23 - is a step towards ensuring stability and reconstruction of post-conflict states.

In spite of the reluctance of the international community to support youth-and particularly education for youthaffected by conflicts, the RET, over the last ten years, has been building expertise and advocating for and pursuing its mission through which more than 500,000 refugee, IDP, and returnee youth have had access to post-primary educational opportunities. Despite this success, it represents a drop in the ocean in light of the existing and increasing numbers of refugee youth waiting and looking for support to pursue their education after primary level. Students who have shown promise in a particular subject should be allowed the chance to develop their capacities and find their exit strategy out of unemployment or harmful situations. In this respect, the individual and socio-economic added value of post-primary education for refugee youth should be generally endorsed by humanitarian actors and decision makers.

Following this, it is important to highlight some key issues that must be considered by policy and decision makers in order to facilitate and support equal access for refugee youth to relevant and high-quality secondary education.

- In the field of education for refugees, education interventions must be gender sensitive (particularly taking into consideration the needs and situations of girls and young women-for instance providing free and available sanitary materials, clothes, and separate toilets for vulnerable young women and girls).

- Education for refugee youth should consider livelihoods training and opportunities for their families. Poverty and the particular lack of income generation is one of the major obstacles to access and complete one's education, particularly after primary level.
- Actors and decision makers at all education levels must ensure measures and systems aiming to recognize and validate programs and learning attainments from the very start. The post-primary curriculum followed by refugees should be recognized by relevant institutional parties capable of making access to tertiary education possible for students.

- Governments, as well as the donor community, supporting education for refugee youth should encourage assessment, certification, and validation of learning achievements within regional and international frameworks, supporting cross-border certificates, exchange of good practices, and co-operation as well as the development of mutual recognition and validation of certificates and systems in a timely manner.

- The donor community should ensure its support to post-primary education (secondary, vocational, tertiary, university) by creating appropriate mechanisms to link humanitarian relief funds with development funds. Individual refugee scholarship programs should be expanded, aiming to make access to tertiary education a right and not a luxurious opportunity for a very small elite group.

- Governments and the international community should facilitate the integration of refugee youth in the national education system. To do so, they must ensure formal or non-formal educational activities in order to facilitate this. For instance, those activities could be catch-up classes, accelerated learning programs, language courses, and so on. Particularly, but not exclusively, distance learning programs must be considered as a method to ensure access to tertiary education for refugees living in remote areas. In that respect, partnerships with the private sector should be encouraged to support the technological aspects of such programs.

It is widely understood that national competitiveness depends on the knowledge and skills of a country's citizens. For that reason, strengthening access to secondary education for youth affected by and living in conflict and postconflict environments is critical in reducing the vulnerabilities of individual lives, but also in impacting positively upon the future of a society in terms of reconstruction and socio-economic development.

\section{Notes}

1. P. Rose and M. Greeley, "Education in Fragile States: Capturing Lessons and Identifying Good Practices" (prepared for the DAC Fragile States Group Service Delivery Work stream, Sub-team for Education Services, 2006), http:// 
www.ids.ac.uk/ids/pvty/pdf-files/Education_and_Fragile_ States.pdf.

2. INEE, "Education and Opportunity: Post-Primary and Income Growth," Policy Roundtable Framing Paper 1, January 2011.

3. "Global Estimates and Trends", International Organisation for Migration (IOM), http://www.iom.int/jahia/Jahia/ about-migration/facts-and-figures/lang/en.

4. "Adolescents and Youth Task Team-Objectives," http://www.ineesite.org/index.php/post/adolescence _and_youth_task_team/.

5. United Nations, "Trends in Total Migrant Stock: The 2008 Revision," http://esa.un.org/migration.

6. Women's Refugee Commission, "Refugee Girls: The Invisible Faces of War" (Pearson Foundation, 2009): 16.

7. Victor Munoz, "Right to Education in Emergency Settings," United Nations Report A/HRC/8/10 (2008).

8. Women's Refugee Commission, "Global Survey on Education in Emergencies" (2004): iii.

9. "The Right to Education Project," http://www.right-to -education.org/node/618.

10. UNHCR, "Refugee Education in Urban Settings. Cases Studies from Nairobi, Kampala, Amman, Damascus" (Geneva: OSTS/DPSM, 2009).

11. Mentioned by the UNHCR High Commissioner, Antonio Guterrez, the 2010 Harrell-Bond Human Rights Lecture, Refugee Studies Centre, University of Oxford, 13 October 2010.

12. Figures at the end of 2003. UNHCR, Protracted Refugee Situations, Standing Committee 30th meeting, EC/54/SC/ CRP.14, 10 June 2004: 2.

13. 1951 Refugee Convention, Article 22(1).

14. 1951 Refugee Convention, Article 22(2).

15. Universal Declaration of Human Rights (1948: Article 26); Geneva Convention (IV) Relative to the Protection of Civilian Persons in Time of War (1950: Articles 24, 50, 94, 108 \& 142); International Covenant on Economic, Social and Cultural Rights (1966: Articles 13 \& 14); Convention on the Elimination of All Forms of Discrimination Against Women 1979: Article 10); Convention on the Rights of the Child (1989: Articles 2, 28, 29 \& 30); Millennium Development Goals (2000: Articles 2 \& 3).

16. See the non-discrimination provisions contained in Article 3 of the ICESCR and Article 2 of the CRC. Article 10 of the CEDAW affirms that women have equal rights with men in terms of education. See also UN Committee on Economic, Social and Cultural Rights (CESCR), General Comment No. 13: The Right to Education (Art. 13 of the Covenant), 1999, paras. 6 and 34 .

17. J. McDonald, "Entitled to Learn? A Report on Young Refugees' Experiences of Access and Progression in the UK system" (London: World University Service, 1995); S. Gaunt, S.
Hudson, and Y. Aferiat, eds., "Good practice guide on the Integration of refugees in the European Union" (The ECRE Task Force, World University Service, 1999).

18. S. Nicolai and K. Triplehorn, "The Role of Education in Protecting Children in Conflict," Network Paper, ODI (London: Humanitarian Practice Network, 2003).

19. The 1951 Refugee Convention, Article 22, states, "The Contracting States shall accord to refugees' treatment as favourable as possible as and in any event not less favourable than the accorded to aliens generally in the same circumstances with respect to ... the recognition of foreign school certificates, diplomas, degrees."

20. UNHCR, "Refugee Education in Urban Settings: Cases Studies from Nairobi, Kampala, Amman, Damascus” (Geneva: OSTS/DPSM, 2009); UNESCO, "Certification validation and recognition of the learning attainments of refugee and internally displaced pupils," http://www.iiep.unesco .org/capacity-development/technical-assistance/ emergencies-and-fragile-contexts/research/partnership -with-the-netherlands-and-irc/certification-validation .html.

21. INEE Policy Roundtable Outcome Report (January 2011).

22. Joint Statement by Heads of UN Entities for the Launch of the International Year of Youth, 2010.

23. Ibid.

Marina L. Anselme, with an MA in social change and cultural behaviour from Paris V, Sorbonne University, and a PhD in social sciences (sociology and demography) from the Sorbonne and Geneva Universities, has more than ten years of working experience in the fields of development and relief. Currently she is the chief of Education Programme Development at the RET, as well as researcher at the University of Applied Sciences of Western Switzerland. Her research focuses particularly on migrant youth behaviour, and attitudes and representations concerning their citizenship roles in their countries of residence.

Catriona Hands has an MA in social anthropology and development studies from Edinburgh University, where she specialized on the role of ethnicity and identity in diasporic settings. She has worked at the RET for two years as research and development analyst, and prior to this worked for a developmental NGO specializing in the provision of education and health care to families and young children affected by HIV/AIDS in Songea, Tanzania. She is enrolled to finish her studies with a second master's degree in conflict studies at SOAS University in London for September 2011. 